\title{
Physical Properties of Shinayaka Hair and Fine Technology to Control Internal Hair Properties*
}

\author{
Yukari Nishita **, Mikako Ezure **, Noriyuki Tanji **, Takashi Mizooku**, \\ Shinobu Nagase ${ }^{* *}$, Takahiro Osumi ${ }^{* *}$, Kazutaka Ishikawa*** \\ ** Hair Care Products Research, Kao Corporation, \\ *** Analytical Science Research, Kao Corporation
}

\begin{abstract}
One of main factors for beautiful hair for Japanese women is the smooth movement of hair strands. The motion of the beautiful hair is flexible, but those strands smoothly return to the original shape, like an elastic material. Such flexible and elastic behavior is preferred in Japan and described as Shinayaka in Japanese. We have found that the Shinayaka hair fiber has a twolayered cortex with different physical properties. The relatively softer ortho-ike cortex tends to distribute in the outer layer of the hair fiber (near hair surface), while stiffer para-like cortex tends to be distributed in the inner layer (near the center of the fiber). On the other hand, non-Shinayaka hair exhibits almost no difference in physical properties between the inner and outer layers of the hair fiber because of its structure or damage by a chemical treatment. In this research, we have developed a new technology to selectively soften the outer layer of the non-Shinayaka hair to realize flexible and elastic behavior through two-layered distribution of physical properties. We have found out that the elasticity of the outer layer of the hair is reduced by a treatment with succinic acid, while the elasticity of the inner layer is kept at constant value. Then, we have confirmed the hair strands become more flexible while keeping their elasticity after the treatment.
\end{abstract}

Key words : human hair fiber, flexible and elastic motion, Shinayaka, ortho-and para-like cortex, two-layer, physical property, succinic acid, inner control technology, beautiful hair, hair strands

\footnotetext{
* Received, July 13, 2016; Accepted, October 19, 2016

** 2-1-3, Bunka, Sumida-ku, Tokyo 131-8501, Japan

*** 1334, Minato, Wakayama 640-8580, Japan
}

doi.org/10.5107/sccj. 51.126

(C) 2017 The Society of Cosmetic Chemists of Japan 


\title{
原著
}

\section{しなやかな髪の力学特性と それを実現する毛髪精密改質技術の開発*}

\author{
西田由香里**, 江連美佳子**，丹 治 範 文**，溝 奥 隆 司**, \\ 長 瀬 忍**, 大角高広**, 石川和高*** \\ **花王株式会社 ヘアケア研究所, ***解析科学研究所
}

\begin{abstract}
髪の理想的な状態については，つや·まとまり・触感などさまざまな視点での研究がある。ここで は，日本人女性の理想の髪の一つである「しなやかさ」という動きを伴う美しさに着目した。しなや かな髪は, たとえば毛束が流体のように連続的に変形する柔らかさと, 乱れても元の形状に戻る弾力 性を兼ね備えている。われわれはまず，しなやかな髪の内部構造と物性について検討した。先天的に しなやかな髪としなやかでない髪の内部構造を比較した結果, 先天的にしなやかな髪は, 弾性率の異 なる二種類のコルテックス細胞の構造の分布に偏り（二層構造）があり, 先天的にしなやかでない髪 はそれらが混在して分布することを見出した。また，それによってしなやかな髪は，表層は柔軟で内 層は弾力がある「二層状態の物性」をもつことがわかった。われわれは，この表層と内層との物性差 が，柔らかさと弾力性の共存する，しなやかな髪の特徵的な性質であると考えた。さらに本研究で は，しなやかでない髪をしなやかな髪に近づける一つの方法として，コ八ク酸によって，毛髪表層を 選択的に柔軟化し，「二層状態の物性」に改質することに成功したので報告する。
\end{abstract}

\section{1. 緒言}

髪の理想的な状態については, つゃ・まとまり・触感な どさまざまな視点での研究がある1) 3)。本研究では, 日本 人女性の理想の髪の一つである「しなやかさ」という動き を伴う美しさに着目した。髪のしなやかさは，たとえば頭 を動かしたときに髮が流体のように連続的・曲線的に変形 できる柔軟性と，元の形状に戻る弾力性を兼亦備えた物性 であると考えた。これに対し，単に柔軟な髪は「コシがな く弱々しい髪」に感じられ，単に弾力性のある髪は「硬く てごわごわした髪」に感じられるため，しなやかではな い。頭髪の動きを議論するとき，その制御因子としては， 毛束を構成する毛髮一本一本の形状と物性が考えられる。 形状が直毛のバージンへアに限っても，そのしなやかさに 個体差があることから，今回は，毛束を構成する一本一本 の毛髪の物性に着目した。外力に対する応答において柔軟 性と弾力性が共存する物性を考えるにあたり，世の中に実 在するしなやかに動くものの，動きの因子に着目した。こ

\footnotetext{
*2016.7.13 受付, 2016.10 .19 採用

** $=131-8501$ 東京都墨田区文花 2-1-3

*** $\overline{\%} 640-8580$ 和歌山市湊 1334
}

こに, 二つの例を示す。一つ目は「竹片」である。竹片は, 維管束と呼ばれる弾性の高い組織と, 柔細胞と呼ばれる圧 縮しやすい組織とからなり，ブナと同程度に硬いのに折れ ずに曲がることができる4)。二つ目は「弓」である。弓の 構造は，弓を引いたときに変形の大きい外側に弾性の低い 材料を，内側に弾性の高い材料を貼り合わせることで，変 形しやすく戻る力が強い物性を実現している5)。このよう に, 物性の異なる構造の複合化（いわゆる複合材料）で, 均質な構造では実現できない力学特性が実現できることが 理解できる。周知のように, 毛髪も複数の構造が組み合わ さった複合体である。それならば，複合材料にみられるよ うな，物性の異なる構造が組み合わさったことに由来する 力学特性があるのではないか, そして, その力学特性は, しなやかな髪に特有のものではないかと考えた。

また，髪には，先天的にしなやかな髪としなやかでない 髪が存在するほか, 日々の生活の中で, たとえばへアカ ラーやパーマなどの化学ダメージやへアアイロンの熱など の物理ダメージの積算などによって，後天的にしなやかで なくなった髪が存在する。そこで, しなやかな髪の力学特 性理解へのアプローチは，まずはじめに，先天的にしなや かな髮としなやかでない髪の特性差（ここでは構造の違い に着目）を取出し，そこから予測できる力学特性を仮説と 
しておくことにした。次に，先天的・後天的を問わずしな やかな髪としなやかでない髪について，その仮説の検証を 行うこととした。

一方，われわれはこれまでに毛髪一本一本の物性を制御 する技術の開発を行ってきた。たとえばグリシルグリシン を毛髪に作用させることにより，毛髪が柔軟化することを 報告している2。本研究では，しなやかな髪の構造上の特 徵から，その物性分布の特徵を解明し，さらにその物性分 布に倣って毛髮物性を精密に制御することで，しなやかで ない髪をしなやかな髪に近づける技術の開発を行った。

\section{2. 実験}

\section{1. 試料毛髪}

先天的な特徵を理解する目的で，日本人女性から採取し た非化学処理毛 10 個体を使用した。これら毛髮をパネリ ス卜（専門研究員） 5 名によるしなやかさの官能評価によ り選別した。選別方法は，各パネリストに 10 個体それぞ れにしなやかさの点数をつけてもらい，5人がつけた点数 の平均点をしなやかさのスコアとして用いることにした。 点数の基準は，パネリストそれぞれが，10個体中最もし なやかな個体を 1 点，最もしなやかでない個体を 10 点と した (Table-1)。

また，後天的にしなやかでなくなった髪として，日本人 化学処理履歴毛（ヘアカラーとパーマを毎月行っているセ ミロング毛の毛先約 $5 \mathrm{~cm}$ をサンプリングして使用）を試 料毛髪とした。この毛髪のしなやかさのスコアは約 8 点で あった。

Table-1 Results of the sensory evaluation.

\begin{tabular}{ccc}
\hline $\begin{array}{c}\text { Sample No. } \\
\text { (hair shape })\end{array}$ & Score & Evaluation \\
\hline 1 (Straight $)$ & 1.6 & Shinayaka \\
2 (Straight $)$ & 1.8 & $\begin{array}{c}\text { Shinayaka } \\
\text { Shinayaka }\end{array}$ \\
3 (Straight $)$ & 3.1 & $\begin{array}{c}\text { Somewhat } \\
\text { Shinayaka }\end{array}$ \\
4 (Straight $)$ & 4.2 & $\begin{array}{c}\text { Somewhat } \\
\text { Shinayaka }\end{array}$ \\
5 (Straight $)$ & 4.3 & $\begin{array}{c}\text { Somewhat } \\
\text { Shinayaka }\end{array}$ \\
6 (Straight $)$ & 4.5 & Non-Shinayaka \\
7 (Straight $)$ & 7.1 & Non-Shinayaka \\
8 (Straight $)$ & 8.5 & Non-Shinayaka \\
9 (Curved $)$ & 9.0 & Non-Shinayaka \\
$10($ Curved $)$ & 9.3 & \\
\hline
\end{tabular}

毛髪内層の曲げ弾性率を測定するため,これらの毛髪の 表層部を剥いだ毛髪を用いた。毛髪表層の剥離は，毛髪を アルミナビーズ中で摚拌し, 毛髮の表層部約 $5 \mu \mathrm{m}$ を削り 取る方法で作製し，試料毛髪とした。

一方，毛髪改質処理には，1 回のへアカラー履歴のある 日本人実態毛にダメージ処理（ブリーチ処理後に洗髪処理 を行い，これを 1 セットとして4セット行った）を行い， 試料毛髮とした。このときのブリーチ処理は，3.33\%過酸 化水素 $/ 0.68 \%$ アンモニア $(\mathrm{pH} \mathrm{10})$ 溶液を, 浴比 $1 ： 1$ で 塗布し, 室温で 30 分間放置後濯ぎ流す操作を行った。ま た，洗髪処理は，シャンプー，コンディショナー, ドライ ヤー乾燥を 12 回繰り返した。ダメージ処理によって, こ の毛髪のしなやかさのスコアは, 処理前の約 3 点から約 7 点に変化した。

\section{2. 毛髪組織構造の観察}

\subsection{1. 透過型電子顕微鏡による観察}

透過型電子顕微鏡（日立製作所製，H-7100 以下，TEM） を用いて，毛髪の横断面の組織を観察した。毛髪断面は， ウルトラミクロトーム（Reichert 社製，ウルトラカットミ クロトーム）を用いて超薄切片（厚さ $200 \mathrm{~nm}$ ）を作製し， $2.0 \%$ 酢酸ウラニル水溶液抒よびシグマアルドリッチ製 電子顕微鏡用鉛染色液 $(0.3 \%$ 硝酸鉛 $($ II $) \cdot 0.3 \%$ 酢酸鉛 $($ II $)$ 三水和物含有）で染色し観察に用いた。

\subsection{2. 蛍光顕微鏡による観察}

毛髪のコルテックス部のオルト様コルテックスと，パラ 様コルテックスの分布を簡便に観察するために，2 種類の 蛍光染料を用いて，染め分ける方法が報告されている6 この方法に習い，フルオレセインナトリウム抢よびスルホ ローダミン 101 で毛髪断面を染め分けた。この断面を, 蛍 光顕微鏡（Carl Zeiss 社製，MPM800，蛍光フィルター： BP 450-490，FT 510，LP520）で観察した。

\section{3. 物性の評価}

試料毛髪の曲げ応力, および短径, 長径を, 毛髪曲げ弾 性計測装置（Dia-Stron Limited 社製，FDAS765/FBS900） を用いて測定した。また，試料毛髪は，濡れた状態から $20^{\circ} \mathrm{C} 65 \%$ RH 雾囲気下で 24 時間静置した後, 同環境下で 測定を行った。

この測定から，曲げ弾性率（曲率およびモーメントで規 格化された曲げ係数）を，一般的な材料力学の関係式》に に より，次のようにして得た。

毛髪を曲げたときに働く力については，式(1)で表される。

$$
\begin{array}{ll}
M=E \times I / \rho & \\
M: \text { 曲げ応力 } & E: \text { 曲げ弾性率 } \\
I: \text { 断面の二次モーメント } & \rho: \text { 曲率半径 }
\end{array}
$$


毛髪断面を楕円とみなし, 長径側の半径を $a$, 短径側の 半径を $b$ とする。また，毛髪を曲げたときは短径側に曲が るとすると，楕円柱の片端を固定した場合の曲げの断面二 次モーメントは $I=\pi \mathrm{ab}^{3} / 4$ となる。さらに, Fig.-1のよう に毛髪を変形させたとき, 変形と応力の関係から, 曲げ弾 性率（E）は式（2）で表される。

$$
\begin{aligned}
& E=4 M L^{3} / 3 \pi \mathrm{ab}^{3} d \\
& L: \text { 毛髪の長さ } \\
& d: \text { 偏向距離 (縦方向 })
\end{aligned}
$$

初期荷重 $2 \mathrm{mg}$ を検知したときを, $d=0 \mathrm{~mm}$ とし, $d=0$ 〜 $0.1 \mathrm{~mm}$ まで, 速度 $0.01 \mathrm{~mm} / \mathrm{s}$ で変形させた。また, 本測 定では $L=2.25 \mathrm{~mm}$ であった。このようにして, 試料毛髪 の曲げ弾性率（ $n=20$ の平均值）を得た。

\section{4. コハク酸による毛髪改質処理}

毛髪表層を柔軟化する成分としてコハク酸を用いた。2 重量\%のコハク酸水溶液 (pH 3.7) を調製し, これにダメー ジ処理を行った毛髪を $40^{\circ} \mathrm{C} て ゙ 30$ 分間浸漬処理することに より, ダメージした毛髪の表層を柔軟化した。

\section{5. 組織弹性率の測定}

2 重量\%のコハク酸水溶液で処理した毛髪の各組織の弾 性率変化を測定した。局所領域の弾性率解析は, 原子間力 顕微鏡（Oxford Instruments 社製，MFP-3D-SA-J）を用いて カンチレバー（Bruker 社製， NCHV）を試料に押し込み， 得られたフォースカーブを Hertz モデルでフィッティング する方法を用いた ${ }^{8)}$ 。試料毛髪を紫外線硬化性樹脂に包埋 した後，纎維軸に垂直な断面を切り出し，表面に近い表層 コルテックスおよび中心付近の内層コルテックスの弾性率 をそれぞれコハク酸処理前後で測定した。

\subsection{DSC 測定による熱力学的解析}

コハク酸の毛髪タンパク質に対する相互作用特性を理解 するため，示差走査熱量計（日立製作所製，DSC7000X， 以下，DSC）による熱力学的解析を行った。試料毛髪は $20^{\circ} \mathrm{C} 65 \%$ RH 雲囲気下で静置し, 調湿した。空の容器を

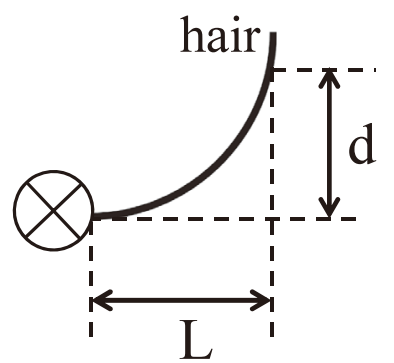

Fig.-1 Schematic diagram showing a measurement image of bending elastic modulus of hair. referenceに用い, 昇温速度は $10^{\circ} \mathrm{C} / \mathrm{min}$ とし, 室温から $-70^{\circ} \mathrm{C}$ まで冷却した後, $250^{\circ} \mathrm{C}$ ま゙昇温を行った。また, 構造の類似した有機酸で毛髪内層部まで浸透しやすいリン ゴ酸9)を用い，2.4. と同様に毛髪を処理し測定に用いた。

\section{3. 結 果と考察}

\section{1. しなやかな髪の特徵}

\subsection{1. 毛髪組織構造の観察}

しなやかな毛髪としなやかでない毛髪について，TEM を用いて断面を観察することにより組織構造の違いを比較 した。Table-1の試料毛髪について, キューティクルやメ デュラの状態には違いを見出せなかった。一方, しなや か・しなやかでない試料毛髪では, コルテックス細胞の分 布が異なっていた。コルテックス細胞には, コルテックス 細胞を構成するマクロフィブリルのインターメディエイト フィラメントが，らせん状に配向したオルト様コルテック スと，纎維軸方向に平行に配向したパラ様コルテックスが 存在する。毛髪断面の観察において, オルト様コルテック スにはミクロフィブリルの円形のパターンがみられる一 方, パラ様コルテックスはミクロフィブリルの境界が明確 でないため, 分類が可能である ${ }^{6)}$ 。しなやかな試料毛髪 No. 1 の TEM 像を Fig. -2 に示す。表層約 $2 \mu \mathrm{m}$ のキュー ティクル層の内側に, 直径 $0.3 \mu \mathrm{m}$ 前後の円形パターンの オルト様コルテックスが約 $3 \mu \mathrm{m}$ の部分に特徵的に配置さ れ，それよりも内層の部分はパラ様コルテックスが特徵的 に配置されていた。このことから，しなやかな髪には、コ ルテックス部の表層部にオルト様コルテックスが, 内層部 にパラ様コルテックスが配置する特徵的構造パターンがあ ることがわかった。さらにオルト様コルテックス，パラ様 コルテックスの分布に着目して毛髪断面を観察するため に, Table-1の試料毛髪各個体から無作為に取り出した, 約 100 個の毛髪切片を 2.2.2. に示す方法で染色し, 蛍光顕 微鏡で観察した。Fig.-3にしなやかな髪としなやかでない 髪の代表的なオルト様・パラ様コルテックス分布を示す。 このとき, オルト様コルテックスは赤色に, パラ様コル テックスは黄緑色に染色される。観察した結果, 先天的に しなやかと評価された毛髪個体には，表層部にオルト様コ ルテックス, 内層部にパラ様コルテックスが局在している ような構造パターンをもつ毛髪が多く観察された。このよ うな構造パターンは, TEM 観察結果とも一致する。一方, しなやかでないと評価された毛髪個体は, オルト様コル テックスとパラ様コルテックスが混在していた。

\subsection{2. 毛髪物性分布}

オルト様コルテックスとパラ様コルテックスとでは弾性 率が異なり, パラ様コルテックスの方が弾性率は高いこと 

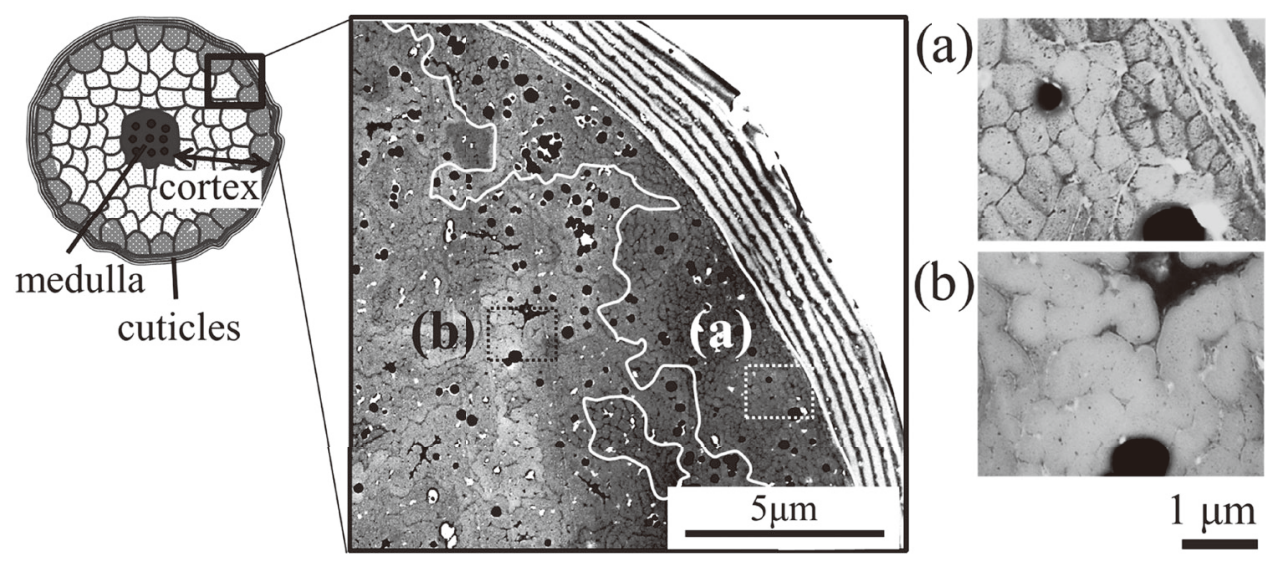

Fig.-2 TEM observation of two types of cortex in a Shinayaka hair (sample No. 1 in Table 1); (a) Ortho-like cortex, (b) Para-like cortex.

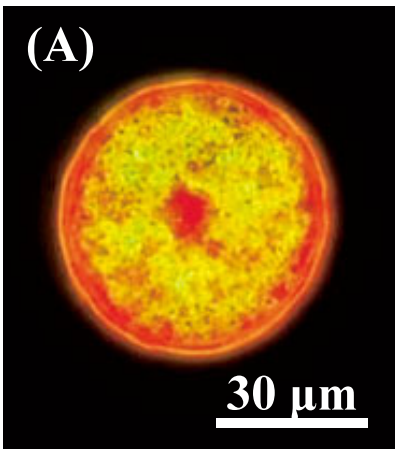

Shinayaka

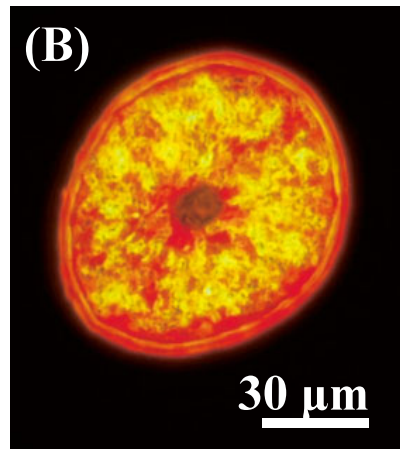

Non-Shinayaka

Fig.-3 Representative images of fluorescently stained cross sections of (A) Shinayaka and (B) nonShinayaka hairs.

が報告されている10),11)。そのことから，しなやかな毛髪 は表層部が内層部と比較して弾性率が低い二重円筒状の物 性分布をもつとの仮説を置き，物性の測定を行った。

試料毛髪の毛髪径および曲げ弾性率, さらに表層部を取 り除いたときの毛髪径および曲げ弾性率を測定した。

毛髪が表層部と内層部の 2 つの筒からなるとした場 合，それぞれの曲げ弾性率を $E_{\mathrm{sur}}$ (表層部)， $E_{\text {in }}$ (内層部) とするとき, 全体弾性率の $E_{\mathrm{total}}$ との関係は, 次式のよう になる ${ }^{12)}$ 。

$$
E_{\text {total }}=E_{\text {sur }}\left(1-r_{\text {ain }} r_{\mathrm{bin}}{ }^{3} / r_{\mathrm{a}} r_{\mathrm{b}}{ }^{3}\right)+E_{\text {in }} r_{\mathrm{ain}} r_{\mathrm{bin}}{ }^{3} / r_{\mathrm{a}} r_{\mathrm{b}}{ }^{3}
$$

ここで， $r_{\mathrm{a}}$ は毛髪長径， $r_{\mathrm{b}}$ は毛髪短径， $r_{\mathrm{ain}}$ は表層を剥 離した毛髪の長径， $r_{\text {bin }}$ は表層を剥離した毛髪の短径であ る。そこで， $E_{\text {total }}, E_{\text {in }}$ の実測值および $r_{\mathrm{a}}, r_{\mathrm{b}}, r_{\mathrm{ain}}, r_{\mathrm{bin},}, の$

実測值と式から，表層部の弾性率（ $\left.E_{\text {sur }}\right)$ を算出した（Fig.$4(\mathrm{~A}))$ 。ここでは直毛の毛髪の中で, 官能評価において 最もしなやかな個体（試料毛髪 No. 1) と最もしなやかで ない個体（試料毛髪 No. 8）を代表例として示す。試料毛 髪 No.1 (しなやかな髪) の測定結果は $E_{\mathrm{sur}}=3.0 \mathrm{GPa}, E_{\mathrm{in}}=$ $5.9 \mathrm{GPa}$ であり, 表層部/内層部の弾性率比 0.51 であっ た。毛髪組織構造の観察から予想したとおり，表層部が柔 らかく内層部は弾力がある二層の物性であることが確認で きた。一方で試料毛髪 No.8（しなやかでない髪）の測定 結果は $E_{\text {sur }}=4.9 \mathrm{GPa}, E_{\mathrm{in}}=5.4 \mathrm{GPa}$ であり，表層部/内層部 の弾性率比 0.90 であった。しなやかな髪と比較して, 表 層部と内層部の物性差が小さく，二層状態はより不明瞭で あった。さらに, Table-1の 10 個体について, しなやかさ の官能評価と各個体の表層部/内層部の弾性率比には相関 があり，表層部と内層部との物性差が大きい個体ほどしな やかであることがわかった（Fig.-4 (B))。また，化学処 理によってしなやかでなくなった毛髪も， $E_{\text {sur }}=5.5 \mathrm{GPa}$, $E_{\mathrm{in}}=5.4 \mathrm{GPa}$ であり, 表層部/内層部の弾性率比 1.03 と, 物性差が小さかった。

以上から, しなやかな髪は, 表層部が柔らかく内層部に 弾力がある「二層状態の物性」をもつことを特徵とし, 先 天的・後天的にかかわらず，しなやかでない髪は，表層部 と内層部の物性差が小さいことがわかった。

\section{2. しなやかな髪を実現する毛髪精密改質技術}

上述の結果は, さまざまな性質の髪を，表層部は柔らか く内層部は弾力がある二層状態にすることで，しなやかな 髪へ改質できる可能性を示す。しなやかでない髪をしなや かな髪の特徵である「二層状態の物性」に近づける一つの 方法として，ここでは毛髪表層を選択的に柔軟化させ，毛 髪の物性を精密に制御する技術について示す。 
(A)

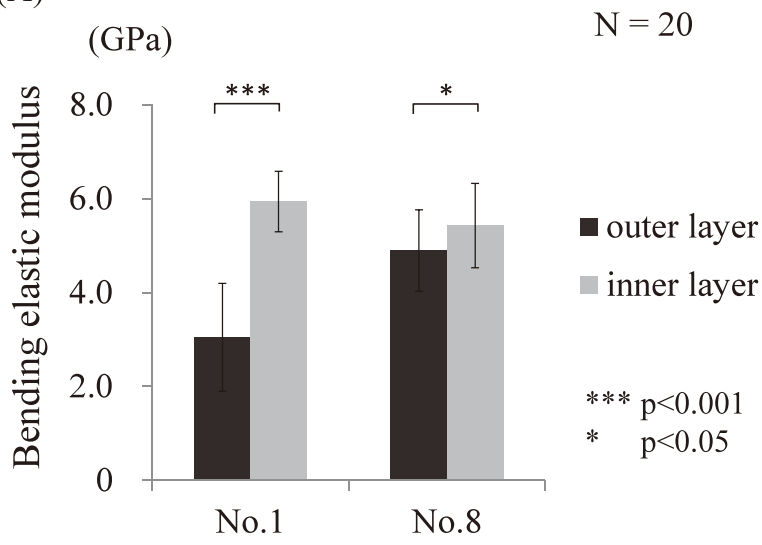

(B)

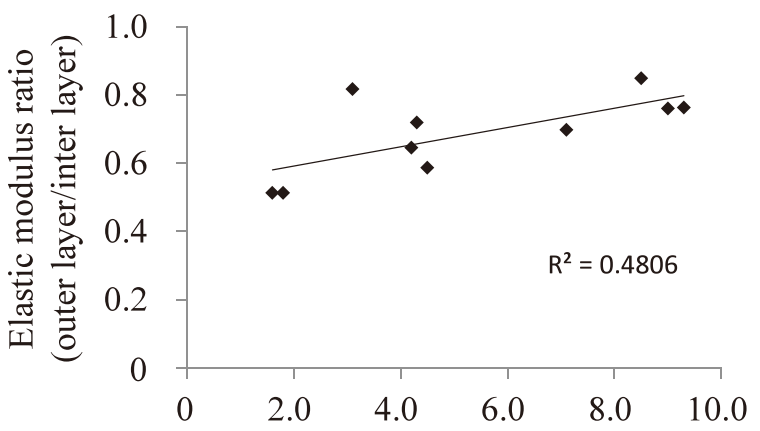

The score of sensory evaluation

Fig.-4 (A) Bending elastic modulus of outer and inner layers of Shinayaka hair (No. 1) and non-Shinayaka hair (No. 8) and (B) correlations between the score of sensory evaluation and elastic modulus ratio (outer layer/inner layer).

\subsection{1. コハク酸で処理した毛髪の物性変化}

有機酸が毛髪を改質しやすいことから ${ }^{2)}$, 種々の有機酸 の中から毛髮表層を選択的に柔軟化させる成分を探索し，

コハク酸を見出した。2.4.に従い，毛髪をコ八ク酸で処理 した結果，しなやかさのスコアは約 7 点から約 3 点に改善 した。コハク酸で処理した毛髪のコルテックス部の弾性率 変化を Fig.-5に示す。表面に近い表層コルテックスは処 理前と比較して弾性率が大きく低下した。一方で中心付近 の内層コルテックスの弾性率変化は小さく，コハク酸処理 後は表層部の弾性率が内層部より小さくなった。このよう にコハク酸は毛髪表層の組織を選択的に柔軟化することが わかった。

さらに, 3.1.2. と同様の方法で得た，コハク酸処理前後 の毛髪表層部㧍よび内層部の曲げ弾性率を Fig.-6 に示す。 コハク酸で処理することによって，表層部の曲げ弾性率が 低下した。このように，コハク酸を用いて毛髪表層部を選 択的に柔軟化することで，表層部と内層部との物性差を大

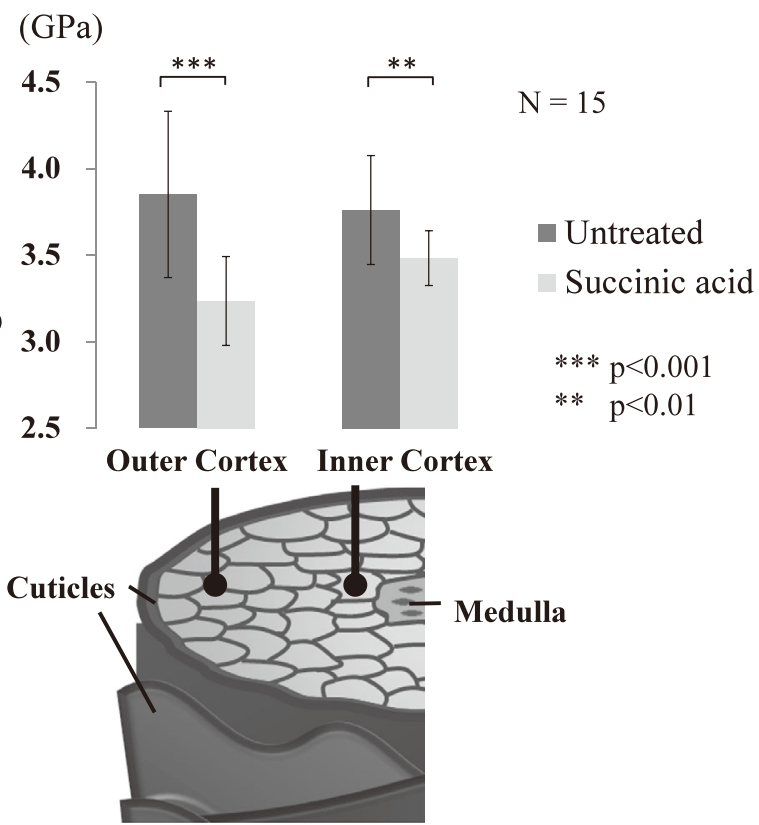

Fig.-5 Elastic modulus ratio of outer or inner cortex.

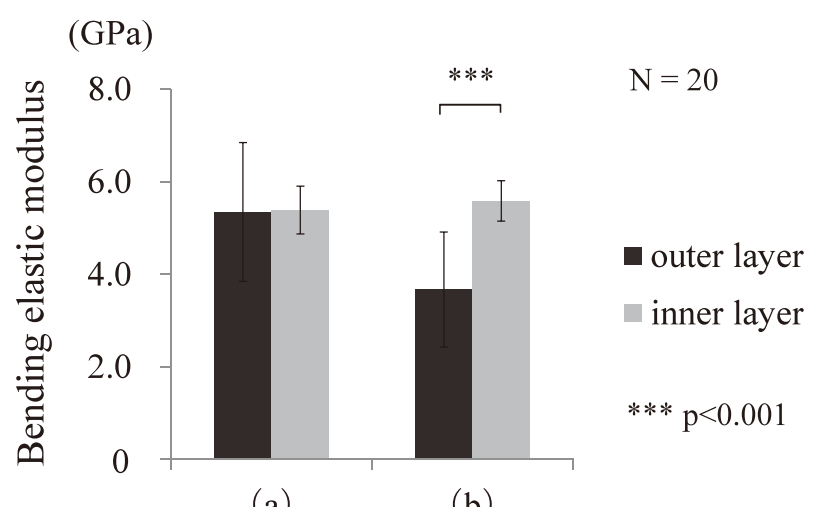

Fig.-6 Bending elastic modulus of outer and inner layers of hair.

(a) Before and (b) after treatment with succinic acid.

きくし，しなやかな髪の特徴である二層状態の物性に近づ けられることがわかった。

\subsection{2. コ八ク酸で処理した毛髪の熱力学的解析}

コハク酸が表層を選択的に柔軟化したことから，コハク 酸は毛髪表層に局在することが考えられた。一方で，同じ 有機酸でも,リンゴ酸は同様の処理で毛髪内層部までより 多く浸透することがわかっている9)。この理由として、コ 八ク酸のほうが毛髪タンパク質に強く作用し，表層に留ま りやすいためと考えた。本研究では，有機酸と毛髮タンパ ク質との相互作用を DSC 測定により熱力学的に解析した。

Fig.-7 に有機酸処理した毛髪の DDSC 曲線掞よびガラス 
転移温度（以下， Tg）を示す。DSCチャートではガラス 転移時のベースラインシフトが確認しにくいため, Fig.-7 ではDSC の微分情報であるDDSC 曲線の変化を示した。 昇温時にガラス転移に伴うピークがみられ，ピークトップ 部分を $\mathrm{Tg}$ とすると，有機酸で処理することで $\mathrm{Tg}$ が低下 する傾向がみられた。リンゴ酸とコハク酸では，コハク酸 処理のほうが Tg が大きく低下した。

$\mathrm{Tg}$ の変化が大きいほどタンパク質との相互作用が大き いと考えられることから，コハク酸はリンゴ酸と比較して 毛髪のタンパク質と強く相互作用し, 毛髪表層部に留まり やすいことが示唆された。また，Tgの低下は，水や有機 酸がタンパク質を可塑化したことを示すことから，コハク 酸が効率的にタンパク質を柔軟化することが考えられ た ${ }^{13) \sim 15) 。 ~}$

以上から, コハク酸は毛髪表層部に局在して柔軟化し, しなやかでない髪をしなやかな髪の特徵である二層状態の 物性に改質することがわかった。

\section{4. 結論}

毛髪のしなやかさとして，本研究では，「変形しやすい 柔軟性」と「元に戻りやすい弾力性」を兼ね備えた物性だ と定義した。われわれは，しなやかな髪の構造上の特徴か ら，その物性分布の特徵を解明し，さらにその物性分布に 倣って毛髪物性を精密に制御することで，しなやかでない

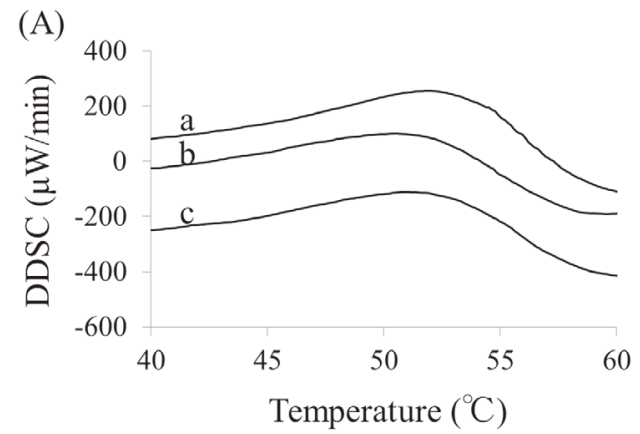

(B)

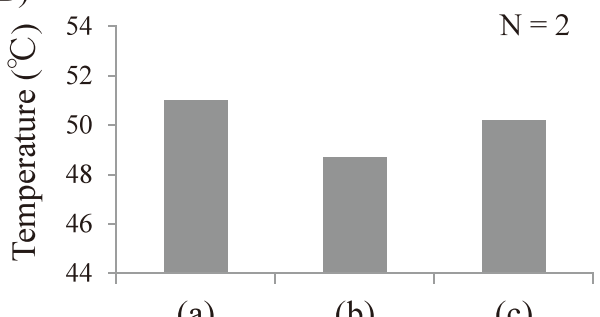

(a)

(b)

(c)

Fig.-7 (A) DDSC curves and (B) glass transition temperature of each hair.

(a) Without treatment, (b) treated with succinic acid, (c) treated with malic acid.
髪をしなやかな髪に近づける技術の開発を行った。

1. 官能評価で分類した先天的にしなやかな髪としなや かでない髪の断面の TEM 観察および, オルト様/パラ様 コルテックスの染め分け法による観察結果から，しなやか でない髪は, オルト様コルテックスとパラ様コルテックス が混在して分布するのに対し，しなやかな髪は，表層部に オルト様コルテックスが, 内層部にパラ様コルテックスが 分布する二層の構造をもつことがわかった。

2. しなやかな髪としなやかでない髪の表層部と内層部 の弾性率の分布を比較した結果，しなやかでない髪は物性 差が小さいのに対し，しなやかな毛髪は表層部が内層部と 比較して弾性率が低く，物性が二層状態であることがわ かった。

3. コハク酸によって毛髪表層を選択的に柔軟化するこ とで，しなやかでない髪をしなやかな髪の特徽である二層 状態の物性へ改質できることがわかった。また，コハク酸 は強い相互作用により毛髪タンパク質に分配・吸着しやす く，より表層に留まって作用することが示唆された。

一般的に，化学処理などのダメージによって毛髪がしな やかでなくなることがしられている。ダメージした髪につ いて, 表層部の曲げ弾性率が高くなり, 物性差が小さくな ることも確認しており，これがダメージした毛髪がしなや かでない理由であると考えられる。われわれは，コハク酸 によって，このような毛髪の表層を選択的に柔軟化し，内 層部・表層部の物性差を大きくすることで，しなやかな髪 を実現することに成功した。また，コハク酸はダメージし た毛髪だけでなく，化学処理履歴のない先天的にしなやか でない髪にも効果があることを確認しているが，これにつ いては別途報告する予定である。

\section{引用文献}

1) S. Nagase, N. Satoh, K. Nakamura, J. Cosmet. Sci., 53, 387402 (2002)

2) S. Breakspear, M. Fukuhara, T. Itou, Y. Hirano, M. Nojiri, A. Kiyomine, S. Inoue, J. Cosmet. Sci., 64, 19-33 (2013)

3) H. Tanamachi, S. Inoue, N. Tanji, H. Tsujimura, M. Oguri, M. Ishita, S. Tokunaga, F. Sazanami, J. Cosmet. Sci., 60, 3144 (2009)

4) E. Obataya, P. Kitin, H. Yamauchi, Wood Sci. Technol., 41, 385-400 (2007)

5）小山弓具, 弓道コラム。 http://www.koyama-kyugu.com/ archive/c017.php

6) W. G. Bryson, D. P. Harland, J. P. Caldwell, J. A. Vernon, R. J. Walls, J. L. Woods, S. Nagase, T. Itou, K. Koike, J. Struct. Biol., 166, 46-58 (2009)

7）建築のテキスト編集委員会 編, 改訂版初めての建築 構造力学, 学芸出版社, 2013 
8）中嶋 健，藤波 想，額賀英幸，渡部浩行，北野宏 樹，大野直人，遠藤克佳，金子美枝，西 敏夫，高分 子論文集，62, 476-487（2005）

9) M. Okamoto, A. Mamada, R. Yakawa, S. Inoue, T. Wakisaka, S. Nagase, S. Shibuichi, N. Satoh, Proceedings of 21 st IFSCC International Congress, Germany, 2000, p.37

10) J. P. Caldwell, W. G. Bryson, Proceedings of 11th International Wool Research Conference, UK, 2005, 89FWS

11) T. Itou, Y. Ezawa, S. Nagase, A. Mamada, S. Inoue, K.
Koike, Abstracts of 7th World Congress for Hair Research, J. Invest. Dermatol., 133, 14-15 (2013)

12) A. Sogabe, M. Yasuda, A. Noda, J. Soc. Cosmet. Chem. Jpn., 36, 207-215 (2002)

13) F. J. Wortmann, M. Stapels, R. Elliott, L. Chandra, Biopolymers, 81, 371-375 (2006)

14) T. Gao, J. Cosmet. Sci., 58, 393-404 (2007)

15) G. V. Scott, C. R. Robbins, J. Soc. Cosmet. Chem., 29, 469485 (1978) 